Pl. Syst. Evol. 260: 199-221 (2006)

DOI $10.1007 / \mathrm{s} 00606-006-0443-8$

Plant Systematics

and Evolution

Printed in Austria

\title{
Floral structure and systematics in four orders of rosids, including a broad survey of floral mucilage cells
}

\author{
M. L. Matthews and P. K. Endress \\ Institute of Systematic Botany, University of Zurich, Switzerland \\ Received November 11, 2005; accepted February 5, 2006 \\ Published online: July 20, 2006 \\ (C) Springer-Verlag 2006
}

\begin{abstract}
Phylogenetic studies have greatly impacted upon the circumscription of taxa within the rosid clade, resulting in novel relationships at all systematic levels. In many cases the floral structure of these taxa has never been compared, and in some families, even studies of their floral structure are lacking. Over the past five years we have compared floral structure in both new and novel orders of rosids. Four orders have been investigated including Celastrales, Oxalidales, Cucurbitales and Crossosomatales, and in this paper we attempt to summarize the salient results from these studies. The clades best supported by floral structure are: in Celastrales, the enlarged Celastraceae and the sister relationship between Celastraceae and Parnassiaceae; in Oxalidales, the sister relationship between Oxalidaceae and Connaraceae, and Tremandraceae embedded in Elaeocarpaceae; in Cucurbitales, the sister relationship between Corynocarpaceae plus Coriariaceae, and the grouping of the core Cucurbitales (Cucurbitaceae, Begoniaceae, Tetramelaceae, Datiscaceae); in Crossosomatales, the sister relationship between Ixerbaceae plus Strasburgeriaceae, and between this clade and Geissolomataceae. The core Crossosomatales (Crossosomataceae, Stachyuraceae, Staphyleaceae) and Celastrales as an order are not strongly supported by floral structure. In addition, a new floral feature of potential systematic interest is assessed. Specifically the presence of special cells in flowers with a thick-
\end{abstract}

ened mucilaginous inner cell wall and a distinct, remaining cytoplasm is surveyed in 88 families and 321 genera (349 species) of basal angiosperms and eudicots. These cells were found to be most common in rosids, particulary fabids (Malpighiales, Oxalidales, Fabales, Rosales, Fagales, Cucurbitales), but were also found in some malvids (Malvales). They are notably absent or rare in asterids (present in campanulids: Aquifoliales, Stemonuraceae) and do not appear to occur in other eudicot clades or in basal angiosperms. Within the flower they are primarily found in the abaxial epidermis of sepals.

Key words: androecium, Celastrales, Crossosomatales, Cucurbitales, gynoecium, Oxalidales.

'Very large', 'poorly understood' but 'well supported' are three good descriptors for the rosid clade (Fig. 1). It comprises perhaps a third of the species of angiosperms and includes 14 orders (Savolainen et al. 2000; Soltis et al. 2000, 2005; APG 2003), of which many have had complex taxonomic histories. Following molecular analyses, new orders have appeared in some cases, such as Crossosomatales (APG 2003), while in others the traditional composition of the orders has been altered, such as in 


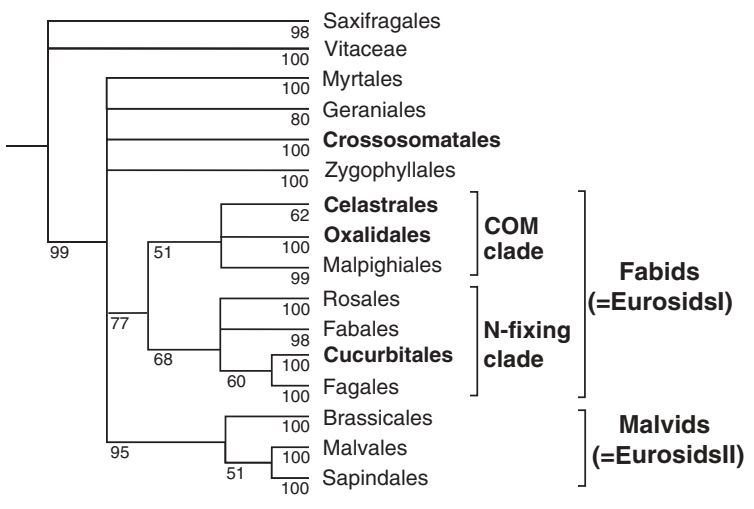

Fig. 1. Cladogram of rosids and potential sister groups (Saxifragales and Vitaceae) (modified after APG 2003 and Soltis et al. 2005, with jackknife values after Soltis et al. 2005). Orders whose floral structure was comparatively studied are highlighted in bold (Matthews and Endress 2002, 2004, 2005a, b)

Cucurbitales (e.g. Zhang et al. 2006). Additionally, floral structure for many members of these orders is either unknown or poorly represented (see also Stevens 2001 onwards, Judd and Olmstead 2004).

In view of this progress in our phylogenetic understanding of rosids, we commenced a project five years ago focussing upon the comparative floral structure of rosid orders with either new or novel circumscription. Our overall aim was to determine whether floral structure (morphology, anatomy and histology) either supports or questions the relationships proposed by molecular phylogenetic studies, and additionally to tease out potential floral synapomorphies for these orders. We aimed to describe the same features in the same way and to ensure that the same features were always described for each study, but adding new features as they emerged. Our motivation based on a common problem faced when surveying literature, that different studies use different terms to describe the same feature or certain features are just not mentioned, all of which leads to confusion.

We have studied four orders to date including Oxalidales (Matthews et al. 2001,
Matthews and Endress 2002), Cucurbitales (Matthews et al. 2001, Matthews and Endress 2004), Crossosomatales (Matthews and Endress 2005a) and Celastrales (Matthews and Endress 2005b). Our reason for selecting these orders of rosids was based upon an initial study comparing what appeared to be the very similar flowers of Cunoniaceae (Oxalidales) and Anisophylleaceae (Cucurbitales) (Matthews et al. 2001, Schönenberger et al. 2001). The ensuing results prompted us to compare the remaining families from these two orders (Matthews and Endress 2002, 2004). When Crossosomatales appeared as a newly circumscribed order (Sosa and Chase 2003, APG 2003) they became our next focus of study (Matthews and Endress 2005a). Finally Celastrales were compared as we had already studied Oxalidales and planned to study Malpighiales in the future, thus completing the COM (Celastrales-Oxalidales-Malpighiales) clade in which these three orders currently form a polytomy. In addition we surveyed one feature, elaborate petals, throughout all orders of the eudicots (Endress and Matthews 2006a).

In this paper we attempt to summarize the results from these four large ordinal studies, specifically mentioning only those special (uncommon) features which are of interest as potential synapomorphies for various clades. Additionally, a new feature of potential systematic interest, special cells in flowers with a thickened mucilaginous inner cell wall is assessed, which has emerged from our intitial studies (Matthews et al. 2001, Matthews and Endress 2002) and was corroborated by the later studies (Matthews and Endress 2004, 2005a,b). We have surveyed the presence of this feature in flowers for 321 genera (349 species) from 88 families of basal angiosperms and eudicots and also assessed the distribution of these cells in leaves based on published records (West 1969; Metcalfe and Chalk 1950, 1979, 1983; Napp-Zinn 1973; Metcalfe 1987; Gregory and Baas 1989; Bakker 1992; Bakker and Gerritsen 1992b; Mariani et al. 1988; Bakker and Baas 
1993; Bredenkamp and Van Wyk 1999). Finally some general comments and conclusions are given with respect to our experience from these broad studies.

\section{Materials and methods}

Survey of mucilage cells. We have used the publications by Metcalfe and Chalk (1950) and Napp-Zinn (1973) to compile a combined list of taxa for which either cells with a mucilaginous inner cell wall and distinct cytoplasm (here called 'special mucilage cells') or entirely mucilaginous cells with an indistinct cytoplasm (here called 'unspecified mucilage cells') are mentioned for vegetative parts. In cases where the names (family or genus) have changed since these publications the new name is used (Appendix I). The ordinal classification is based on APG (2003), and Kårehed (2001) is used for Icacinaceae.

Metcalfe and Chalk (1950) mention 69 families whose leaves have a mucilaginous epidermis, and of these, 13 are described as having cells with a mucilaginous inner cell wall. Napp-Zinn (1973) mentions 14 families for which the inner wall of all or most cells of one or both of the leaf epidermises are mucilaginous, and nine families for which he supposes the cells are "mimicking" an epidermis which is more than one-cell-layered, but is in fact only one cell layer. In this second case ("mimic"), the families are noted in Appendix I but are not included in the overall discussion as it is not certain that they represent our special mucilage cells. Gregory and Baas (1989) mention 129 families whose leaves contain mucilage.

Using this compiled list we surveyed microtome sections (mainly paraplast and some plastic) of flowers from representatives of all families mentioned (unless material was unavailable) from a large collection of microtome sections of PKE, located in the Institute of Systematic Botany, Zurich. Because this material was not originally prepared for this study the number of species surveyed per family was not proportional. In total, flowers from 88 families (321 genera and 349 species) of basal angiosperms and eudicots were surveyed for the presence or absence of these cells and type of mucilage cell noted. Approximately 74 families of the 86 families listed by Metcalfe and Chalk (1950) and Napp-Zinn (1973) were surveyed. The additional families were from our own ordinal studies (Matthews et al. 2001; Matthews and Endress 2002, 2004, 2005a, b). Special mucilage cells are clearly recognisable in plastic-embedded material, less so in the paraplast sections, although best attempts were made. In cases where it was not possible to clearly distinguish between the two cell types (in paraplast sections), the species was noted as having unspecified mucilage cells. Species were assigned to having special mucilage cells only when clearly visible cytoplasm was present (positioned almost always to the outside of the mucilaginous cell wall) including cases where the cytoplasm was reduced but still clearly visible (e.g. Fig. 9 Strasburgeria robusta). In other cases, both special and (what appeared to be) unspecified mucilage cells were present in the same epidermis (e.g. Fig. 3 Connarus conchocarpus), however, always in these cases the presence of special mucilage cells was clearly evident. Advanced buds or anthetic flowers were observed.

Results of our survey are listed in Appendix I and summarized in Tables 1 and 2. Appendix $I$ and the Tables 1 and 2 also include the presence of unspecified mucilage cells in leaves (West 1969; Metcalfe and Chalk 1950, 1979, 1983; Napp-Zinn 1973; Metcalfe 1987; Gregory and Baas 1989; Bakker 1992; Bakker and Gerritsen 1992b; Bakker and Baas 1993) and flowers (our survey plus Endress and Igersheim 1997, 1999; Igersheim and Endress 1997; Merino Sutter et al. 2006). The families originally listed by Solereder $(1899,1908)$ as having a mucilaginous "inner" membrane are also compared (and listed) in Appendix I, but like Napp-Zinn (1973) we could not be 
certain that these cells were the same as our special mucilage cells. For this reason they are also not included in the overall discussion of the systematic distribution of these cells.

Character mapping for the (partial) presence or absence of special mucilage cells in orders of eudicots (Fig. 11) was performed using the soft polytomy (uncertainties of resolution) setting of Maclade 4.07. It was not our intention to hypothesise the evolution of this character within the eudicots (as such evolutionary hypotheses are currently impossible due to the lack of resolution of between clades), but rather to show its distribution.

\section{Results and discussion}

Floral structure and molecular phylogenetic data: congruence or incongruence for the orders Celastrales, Oxalidales, Cucurbitales and Crossosomatales

\section{Celastrales}

Molecular phylogenetic support. Celastrales (Celastraceae, Parnassiaceae and Lepidobotryaceae) are well supported (Savolainen et al. 2000, Zhang and Simmons 2006), and Lepidobotryaceae appear as sister to Celastraceae plus Parnassiaceae (including Lepuropetalon) with good support. Less clear is the relationship between Celastraceae plus Parnassiaceae: based on $r b c \mathrm{~L}$ alone, they form a well supported sister pair (Savolainen et al. 2000). However in the six-gene (three nuclear and three plastid plus one plastid spacer) analysis by Zhang and Simmons (2006), Celastraceae are not monophyletic, but form a polytomy with Parnassiaceae, and thus Parnassiaceae may be nested within Celastraceae. Regardless, a close relationship between Celastraceae and Parnassiaceae is clearly supported. The inclusion of six smaller families (Brexiaceae, Canotiaceae, Hippocrateaceae, Plagiopteraceae, Siphonodontaceae, Stackhousiaceae) into an enlarged Celastraceae is also supported
(Savolainen et al. 2000; Soltis et al. 2000; Simmons et al. 2001a,b; Zhang and Simmons 2006).

Floral structural support. Floral structure strongly supports the close relationship between Celastraceae plus Parnassiaceae (Matthews and Endress 2005b), but does not strongly support the order as a whole (Fig. 2a). Rather, Lepidobotryaceae were found to share interesting features mainly with Malpighiales and to a lesser degree with Oxalidales than with other Celastrales. Those shared with Malpighiales include the presence of ten fertile stamens in two whorls and crassinucellar, pachychalazal, epitropous ovules with an obturator and strong vascularization around the chalaza. However one feature of the gynoecium that does link the three families of Celastrales is the postgenital fusion of the ventral slit by conspicuously long, interlocking epidermal cells. Pronounced protandry involving the movement and/or abscission of stamens is a potential synapomorphy for Celastraceae plus Parnassiaceae, as are a perianth with fringed margins (also Malpighiales and Oxalidales) and commissural stigmas (only these two families out of the 24 families we have studied in our ordinal studies have commissural stigmas, the others have carinal ones). The enlarged Celastraceae (Canotiaceae and Plagiopteraceae not studied) are strongly supported as a group by floral structure, specifically by the presence of an apical septum in the ovary and oxalate druses in the floral organs (both of which are not found in Parnassiaceae or Lepidobotryaceae).

\section{Oxalidales}

Molecular phylogenetic support. Oxalidales are well supported as a clade (Savolainen et al. 2000; Soltis et al. 2000, 2005; Davies et al. 2004; Zhang and Simmons 2006) as are some of the relationships within the order, such as Oxalidaceae plus Connaraceae (Savolainen et al. 2000, Davies et al. 2004, Soltis et al. 2005, Zhang and Simmons 2006) which are sister to 
the remaining families. However, resolution between the remaining families (Brunelliaceae, Cunoniaceae, Cephalotaceae, Elaeocarpaceae including Tremandraceae) is lacking (Savolainen et al. 2000, Davies et al. 2004, Soltis et al. 2005).

Floral structural support. Our original interpretation of floral structural support for Oxalidales and the relationships within it (Matthews and Endress 2002) was based upon the $r b c \mathrm{~L}$ phylogeny by Savolainen et al. (2000), for which all seven families were sampled. However, with the newly proposed close relationship between Brunelliaceae and Cephalotaceae based on $r b c \mathrm{~L}$ plus $t r n-\mathrm{L} t r n \mathrm{~F}$ (Davies et al. 2004), it is appropriate to reassess our results (Fig. 2b). Brunelliaceae and Cephalotaceae share isomerous, apetalous flowers with two whorls of stamens, lack of special mucilage cells (also Oxalidaceae and Elaeocarpaceae), carpels extremely reflexed when the flower is in the female phase, a stigma that is decurrent for almost the entire length of the style and lack of a zig-zag micropyle. Cunoniaceae plus (Brunelliaceae + Cephalotaceae) (Davies et al. 2004) share only very few special floral features, and most are found elsewhere within the order. A potential shared feature is free carpels (or only united at the very base) (Cephalotaceae, Brunelliaceae and some Cunoniaceae e.g. Acsmithia).

Oxalidaceae and Connaraceae as sisters, and Tremandraceae embedded in Elaeocarpaceae, are the two most surprising relationships to result from molecular analyses with respect to Oxalidales (Savolainen et al. 2000, Soltis et al. 2000, Davies et al. 2004, Zhang and Simmons 2006). In both cases, the families had previously not been considered to be closely related and were far apart in traditional classifications (e.g. Cronquist 1981). However, both relationships are strongly supported by floral structure. Specifically, Oxalidaceae and Connaraceae share dimorphic and trimorphic heterostyly (for Oxalidaceae: e.g. Trognitz and Hermann 2001; for Connaraceae: e.g. Lemmens 1989), petals postgenitally hooked together into a tube near the base but free directly at the insertion zone, haplostemonous androecium with stamens congenitally united into a short tube via antepetalous staminodes, hemianatropous to orthotropous ovules, and multicellular glandular hairs on petals, stamens and gynoecia.

Strongest floral structural support was found for the relationship between Elaeocarpaceae and Tremandraceae (despite poor molecular phylogenetic support of Elaeocarpaceae as a whole). These families share, in addition to a number of features commonly associated with a buzz-pollination syndrome, some very unusual features such as involute valvate broad and massive, 3-traced petals that enwrap a group of stamens in bud, ovary locule walls and ovules with hairs, and ovules with a curved chalazal appendage.

\section{Cucurbitales}

Molecular phylogenetic support. Support for the circumscription of Cucurbitales has improved significantly over the last five years (Savolainen et al. 2000; Schwarzbach and Ricklefs 2000; Soltis et al. 2000, 2005; Wagstaff and Dawson 2000; Zhang and Renner 2003; Zhang et al. 2006) and since its expansion to include three new families (Coriariaceae, Corynocarpaceae, Anisophylleaceae) in addition to the traditional core Cucurbitales (Cucurbitaceae, Begoniaceae, Datiscaceae, Tetramelaceae), its composition of seven families have remained the same. However the relationships between these families are still essentially unresolved, and only Anisophylleaceae as sister to the rest of the order (Zhang and Renner 2003, Soltis et al. 2005, Zhang et al. 2006), and Corynocarpaceae plus Coriariaceae appear well supported (Savolainen et al. 2000; Soltis et al. 2000, 2005; Zhang and Renner 2003; Zhang et al. 2006). Resolution within the core Cucurbitales remains unclear, although they consistently form a clade in recent phylogenetic analyses and are especially well supported in Zhang et al. (2006).

Floral structural support. Floral structural studies (Matthews et al. 2001, Matthews and 
Endress 2004) strongly support the two main clades of Cucurbitales, that of Corynocarpaceae plus Coriariaceae, and the core Cucurbitales (Fig. 2c). They also reflect the uncertainty in resolution of the core group. Anisophylleaceae however, remain an enigma, and although sharing features with the rest of the order, still do not fit comfortably within it, seemingly sharing some special features with Oxalidales.

Corynocarpaceae and Coriariaceae share a suite of unremarkable (plesiomorphic?) widespread features, which separate them from the remaining five families, such as bisexual flowers, quincuncial sepal aestivation, diplostemony, superior ovary, and carpels with a single, pendant, syntropous ovule (for additional features see Matthews and Endress 2004).

The core Cucurbitales are supported by floral features such as an extensive roof over the inferior ovary with the free carpel parts very widely spaced, branched placentae (more than bifurcate), ovules with a large-celled surface, and flanks of the outer integument that bulge over the funicle.

The entire order shares carpels that are completely free immediately above the ovary and four of the families are linked by unifacial stigmas and/or styles with pollen tube transmitting tissue that is not connected to the morphological surface for some distance (Corynocarpaceae, Coriariaceae, Tetramelaceae, Begoniaceae).

Anisophylleaceae share with some of the other members of Cucurbitales unisexual flowers, an inferior ovary, and an inner integument which is delayed in development (e.g. Anisophylleaceae: Tobe and Raven 1987; Datiscaceae: Matthews and Endress 2004; Cucurbitaceae: Singh 1955; Begoniaceae: Anisimova 1983). With Oxalidales, they share for example an obdiplostemonous androecium, special mucilage cells (for details see next chapter) in the epidermis of sepals and gynoecium, and elaborate petals with finger-like lobes (see also Matthews et al. 2001, Endress and Matthews 2006a). Based on floral structure and the lack of strong support for the relationships within the nitrogen-fixing clade and between this clade and the COM clade, the position of Anisophylleaceae should be investigated further.

\section{Crossosomatales}

Molecular phylogenetic support. Crossosomatales appear as a newly circumscribed and well supported order in APG (2003) comprising three families (Crossosomataceae, Stachyuraceae, Staphyleaceae) (Savolainen et al. 2000; Soltis et al. 2000, 2005; Cameron 2003; Sosa and Chase 2003). The order is associated with a second clade of four families (Aphloiaceae, Geissolomataceae, Ixerbaceae and Strasburgeriaceae) (Savolainen et al. 2000; Soltis et al. 2000, 2005; Cameron 2003; Sosa and Chase 2003) and of these, only the sister pair Ixerbaceae and Strasburgeriaceae receive strong support (Savolainen et al. 2000, Cameron 2003, Sosa and Chase 2003). Geissolomataceae, sister to Ixerbaceae plus Strasburgeriaceae, is weakly supported and the enlarged order of all seven families receives no molecular support (Soltis et al. 2000, 2005; Cameron 2003). Additionally, the position of Aphloiaceae within the order is not yet stable (Savolainen et al. 2000; Soltis et al. 2000, 2005; Cameron 2003; Sosa and Chase 2003; Davies et al. 2004).

Floral structural support. Ixerbaceae and Strasburgeriaceae as a clade have excellent floral structural support (Fig. 2d). They share large solitary flowers with special mucilage cells plus unspecified mucilage cells (for details see next chapter), both cell types present within the mesophyll (but not epidermis) of all or most floral organs. Additionally they share antitropous ovules and lignified, unicellular Tshaped hairs on floral organs. Similar unusal hairs are also found on vegetative organs of Geissolomataceae (Dahlgren and Rao 1969), and provide good support for the relationship suggested between these three families in molecular studies, in addition to alternisepalous carpels, a punctiform stigma formed by postgenitally united and twisted carpel tips, synascidiate ovary and only one or two pendant ovules per carpel. 
Despite non-existent molecular support for the expanded Crossosomatales, the group shares a number of very particular floral structural features, such as the presence of gynoecia with postgenitally united carpel tips (containing a compitum) and a free region below, plus cell clusters with bundles of yellow crystals (see Matthews and Endress 2005a, for additional features). Aphloiaceae and Crossosomataceae have never been shown to be closely related in any molecular analyses, yet they share a suite of features that are not present in the other members of the order, such as a polystemonous androecium with basifixed anthers, stigma with two decurrent crests, campylotropous ovules and reniform seeds and an absence of hairs on flowers. In contrast, core Crossosomatales, which consistently receive high molecular support, show only minimal floral structural similarity, as the features linking them are particularly unremarkable: polygamous or functionally unisexual flowers, $\mathrm{x}$-shaped anthers, and free and follicular carpels (not Stachyuraceae).

New feature of interest in flowers: Mucilage cells with unequally thickened inner tangential cell wall and distinct remaining cytoplasm

Cells with a mucilaginous inner tangential cell wall and a distinct remaining cytoplasm (special mucilage cells) in floral organs have not, to our knowledge been reported before, yet they represent a new feature of potential systematic interest. These cells, first observed in flowers of Cucurbitales (Anisophylleaceae: Anisophyllea, Polygonanthus) and Oxalidales (Cunoniaceae: Gillbeea, Geissois) (Matthews et al. 2001, Matthews and Endress 2002) have since been observed in additional families within Oxalidales (Connaraceae, Tremandraceae; Matthews and Endress 2002), in Crossosomatales (Ixerbaceae, Strasburgeriaceae; Matthews and Endress 2005a) and in Perrottetia (Matthews and Endress 2005b; now placed in malvids, close to Dipentodon and Tapisca, Zhang and Simmons 2006). Our initial observations revealed that such cells are present in sepals and sometimes also in the gynoecium (Geissois, Anisophyllea), but are rarely present in all floral organs (only Strasburgeria; Matthews and Endress 2005a). They are concentrated in the epidermis and less commonly in the hypodermis, and in the sepals primarily on the abaxial side, sometimes also or only on the adaxial side. How is their distribution in the light of molecular phylogenies?

In vegetative organs the presence of such special mucilage cells has long been known and their systematic distribution received most attention one hundred years ago (e.g. Tschirch 1889; Walliczek 1893; Solereder 1899, 1908). Later studies mention but do not concentrate on them (reviews in Metcalfe and Chalk 1950, Napp-Zinn 1973). However, both Lyshede (1977, Spartocytisus, Fabaceae) and Bredenkamp and Van Wyk (1999, Passerina, Thymelaeaceae) detail the development of these cells.

Background mucilage cells. Two general points emerge from the literature on mucilage cells (1) the constancy of the location of the mucilage between the primary cell wall and plasmalemma (e.g. Mollenhauer 1967, Fahn 1979, Mauseth 1980, Trachtenberg and Fahn 1981, Bakker and Gerritsen 1992a) and the content and origin of the mucilage (composed mainly of polysaccharides, especially pectins, and sometimes containing proteins and synthesised mainly by Golgi bodies; Mollenhauer 1967; Bouchet 1973; Lyshede 1977; Fahn 1979, 1988; Trachtenberg and Fahn 1981), plus (2) the variability of their function in different organs and taxa. Overlaying all of these functions however is their overall potential to absorb water and swell.

In leaves, typically mucilage cells are present in the adaxial epidermis and are larger than the surrounding cells, often protruding into the underlying cell layer (Gregory and Baas 1989, Bakker and Gerritsen 1992a). Mucilage tends to be deposited in concentric layers between the cell wall and the cytoplasm (extraplasmatic space), these layers are visible in microtome sections as bands or striations of the mucilaginous wall (e.g. Bakker and Gerritsen 1992a; Figs. 3 and 5, this study). The location (and fate) of the cytoplasm in mucilage cells varies, depending on how much, and on which wall(s) 
the mucilage is deposited, but typically, as the volume of mucilage increases, the volume of the cytoplasm decreases and either disappears (Mollenhauer 1967, Bakker and Gerritsen 1992a) or is only visible as a dark line (Mauseth 1980), present either in the centre of the cell, or it is pushed to either the inner or the outer wall.

Background special mucilage cells. The above background briefly details what is known of mucilage cells in general. Our focus is specifically on cells with a thickened mucilaginous inner cell wall and a prominent remaining cytoplasm, and their occurrence in flowers. Details of such cells in the literature are sparse, they appear to be lacking for flowers before Matthews et al. (2001), but were covered for leaves in most detail by German botanists in the late 1800s (e. g. Volkens 1887, especially Walliczek 1893, Solereder 1899). Figures of such cells however do appear in various publications, but are not focussed upon or mentioned specifically, for example in Salicaceae (Mariani et al. 1988; Fig. 3a) and in Thymelaeaceae (Metcalfe and Chalk 1950; Fig. 284). Seeds are the only floral parts mentioned to have cells with unequally thickened, mucilaginous cell walls, however it is the outer wall that is thickened (Fahn 1974, Corner 1976) and not the inner. In Malvaceae reproductive organs, primarily fruits are mentioned (e.g. Mollenhauer 1967, Scott and Bystrom 1970), but the cells appear to be entirely mucilaginous (or forming mucilage cavities derived from a group of cells).

According to Walliczek (1893) and Solereder (1899), mucilage cells in the leaf epidermis are one-sided and the inner cell wall is secondarily thickened (less often the outer wall). The cells occur either singly, or less often as groups of cells or making up the entire epidermis (rarely present in the hypodermis). They are usually always found on the adaxial leaf surface, more rarely on the abaxial (Walliczek 1893, Solereder 1899, Mariani et al. 1988, Bredenkamp and Van Wyk 1999). Special mucilage cells tend to be larger than the surrounding cells and often appear stratified in Salix (Salicaceae) (Mariani et al. 1988) and Passerina (Thymelaeaceae) species (Bredenkamp and Van Wyk 1999).

Our survey. Special mucilage cells in both flowers (our original observations) (Figs. 3-10) and leaves (published records) are concentrated within rosids among angiosperms (monocots not considered) (Table 1, Fig. 11, Appendix I). They have a limited presence in asterids and were not observed in other eudicots or basal angiosperms. The absence of mucilage cells in general from leaves of asterids such as Asterales and Dipsacales has been noted before (Gregory and Baas 1989).

In rosids, special mucilage cells in flowers are most common in fabids (Table 1), present in all orders of both the nitrogen-fixing clade (Fabales, Rosales, Cucurbitales, and Fagales) and parts of the COM clade (Oxalidales and Malpighiales). They were not found in Celastrales. Perrottetia (previously Celastraceae) in which they occur has been moved from Celastraceae to malvids (near Dipentodon and Tapsica; Zhang and Simmons 2006), where such cells are less widely distributed, recorded in only Malvales (and Perrottetia, see above). Outside of eurosids, they also occur in Crossosomatales. In asterids, special mucilage cells in flowers were only found in Aquifoliales.

The systematic distribution of special mucilage cells in leaves is similar to that of flowers, being most common in rosids (Table 1). Within fabids they are present in Fabales and Rosales of the nitrogen-fixing clade and in Oxalidales and Malpighiales of the COM clade. They are present in members of all orders of malvids and also in Myrtales. Within asterids they are present in Ericales and Gentianales.

Special mucilage cells appear to be slightly more common in leaves (present in $24 \%$ of families surveyed) than in flowers (present in $18 \%$ of families surveyed), although this difference could be the result of uneven sampling, with more leaves sampled than flowers. As yet only five families show the presence of special mucilage cells in both their flowers and leaves (Malpighiales: Ochnaceae, Violaceae; 
Table 1. Summary of presence of special mucilage cells in floral organs and/or leaves. The cells may occur in the epidermis (or subepidermis) or mesophyll (rare) of floral organs; in leaves they are only recorded for the epidermis. Presence in floral organs based on our original observations (microtome sections) plus personal communication by M. von Balthazar (Malvaceae (Bombacaceae) and A. Kocyan (Dipterocarpaceae), Merino Sutter et al. (2006); presence in leaves based on literature for which a thickened mucilaginous inner cell wall is clearly mentioned (Metcalfe and Chalk 1950, 1979; Napp-Zinn 1973; Bredenkamp and Van Wyk 1999). Those cases where the cells are described as "mimicking two cells" (NappZinn 1973) or with a mucilaginous 'inner' membrane (Solereder 1899, 1908) are not included

\begin{tabular}{|c|c|c|c|}
\hline Order & Family & Flowers & Leaves \\
\hline \multirow[t]{2}{*}{ Crossosomatales } & Ixerbaceae & + & - \\
\hline & Strasburgeriaceae & + & - \\
\hline Myrtales & Vochysiaceae & $?$ & + \\
\hline Cucurbitales & Anisophylleaceae & + & - \\
\hline \multirow[t]{2}{*}{ Fabales } & Fabaceae (papilionoids) & - & + \\
\hline & Fabaceae (caesalpinioids) & + & - \\
\hline \multirow[t]{3}{*}{ Rosales } & Moraceae & - & + \\
\hline & Rosaceae & - & + \\
\hline & Ulmaceae & + & - \\
\hline Fagales & Fagaceae & + & - \\
\hline \multirow[t]{3}{*}{ Oxalidales } & Connaraceae & + & + \\
\hline & Cunoniaceae & + & + \\
\hline & Tremandraceae & + & - \\
\hline \multirow{7}{*}{ Malpighiales } & Euphorbiaceae & - & + \\
\hline & Picrodendraceae & + & - \\
\hline & Ochnaceae & + & + \\
\hline & Rhizophoraceae & + & - \\
\hline & Salicaceae & - & + \\
\hline & Trigoniaceae & $?$ & + \\
\hline & Violaceae & + & + \\
\hline Malvids & Perrottetia & + & - \\
\hline \multirow[t]{2}{*}{ Brassicales } & Brassicaceae & - & + \\
\hline & Resedaceae & - & + \\
\hline \multirow[t]{3}{*}{ Malvales } & Cistaceae & + & - \\
\hline & Malvaceae & - & + \\
\hline & Thymelaeaceae & - & + \\
\hline \multirow[t]{2}{*}{ Sapindales } & Rutaceae & - & + \\
\hline & Sapindaceae & - & + \\
\hline \multirow[t]{3}{*}{ Ericales } & Ericaceae & - & + \\
\hline & Fouquieriaceae & - & + \\
\hline & Theaceae & - & + \\
\hline Gentianales & Gentianaceae & - & + \\
\hline Aquifoliales & Stemonuraceae & + & - \\
\hline
\end{tabular}

Present (+)/; Absent(-); /not studied (?)

Oxalidales: Connaraceae, Cunoniaceae, Tremandraceae) (for leaves of Tremandraceae see Solereder 1899). Additionally, the presence of special mucilage cells in flowers within a family or genus may not be consistent (e.g. in Viola).

The distribution of unspecified mucilage cells is also surveyed in flowers and leaves 

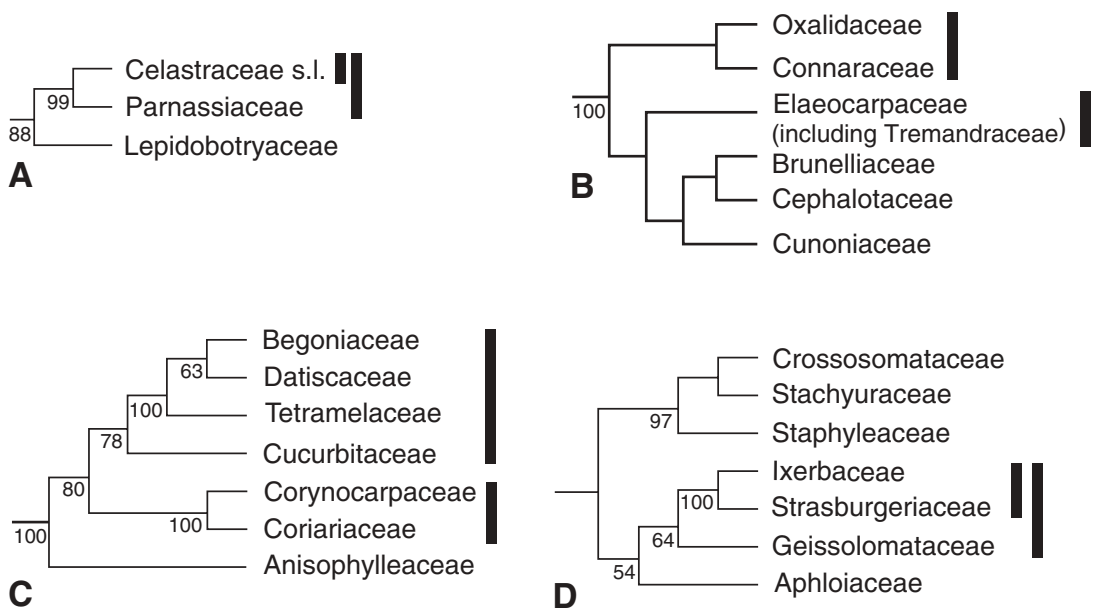

Fig. 2. Best supported clades (solid vertical bar) by floral structure, plus jackknife or bootstrap values. A Celastrales (Savolainen et al. 2000). B Oxalidales (Davies et al. 2004: support values for individual clades are not given by Davies et al. 2004; the support value for the entire order is taken from Soltis et al. 2005). C Cucurbitales (Zhang et al. 2006). D Crossosomatales (Sosa and Chase 2003)

(Table 2, Appendix I). Their distribution is similar to that of special mucilage cells in that they are concentrated in rosids, but their overall distribution is much more widespread. Such cells are present to varying degrees throughout non-monocot angiosperms, including basal angiosperms and core eudicots, although again to a lesser degree in asterids than in rosids. They were not recorded from flowers in asterids (with the exception of Desfontainiaceae) and are significantly more widespread in leaves than they are in flowers. In almost all cases (but not in Ixerbaceae and Strasburgeriaceae in Crossosomatales, Cunoniaceae in Oxalidales), when present in flowers they are similarly present in leaves of taxa from the same family (although the same taxa were not studied for a given family).

Among basalmost angiosperms, unspecified mucilage cells occur in leaves of Illiciaceae, Schisandraceae, Trimeniaceae (Metcalfe 1987), and also in flowers (carpels) of the same families (Endress and Igersheim 1997). Among magnoliids, they occur in leaves of Magnoliales (Annonaceae, Myristicaceae and Laurales (Lauraceae)) (West 1969; Metcalfe 1987; Bakker 1992; Bakker and Gerritsen 1992b,c; Bakker and Baas 1993), and also in flowers (carpels) of
Laurales (Calycanthaceae, Hernandiaceae, Lauraceae, Monimiaceae, Endress and Igersheim 1997), but were not found in flowers of Magnoliales (Igersheim and Endress 1997, except in carpels of Myristica, this study). Among basal eudicots, mucilage cells in leaves were recorded from Menispermaceae (Metcalfe and Chalk 1983); however, in flowers (carpels), probable mucilage cells were only found in Buxaceae (Endress and Igersheim 1999).

Among core eudicots unspecified mucilage cells are present in leaves of all orders of rosids (rare in Geraniales and Celastrales), plus Gunnerales, Berberidopsidales, Dilleniaceae, Caryophyllales, Santalales, Saxifragales and Vitaceae. In asterids they are more widespread than special mucilage cells, present in leaves of Cornales and Ericales, the lamiid orders, Gentianales, Lamiales and Solanales, and in the campanulid order, Aquifoliales.

This survey has identified a potential systematic pattern in the distribution of special (and unspecified) mucilage cells within the rosids. This pattern was earlier not apparent as many of the orders were previously not considered to be closely related. For example Gregory and Baas (1989) note that the orders Ericales, Fabales, Fagales, Rosales, Rham- 
Table 2. Summary of presence of unspecified mucilage cells in flowers and/or leaves of basal angiosperms and eudicots (monocots not considered). The cells occur mainly in the mesophyll of floral organs (rarely in the epidermis) and in the epidermis, hypodermis or mesophyll of the leaves. Presence in floral organs based on our original observations (and in addition personal communication by M. von Balthazar (Malvaceae (Bombacaceae)) and A. Kocyan (Dipterocarpaceae), Endress and Igersheim 1997, 1999, Igersheim and Endress 1997; Merino Sutter et al. 2006 for basal angiosperms and basal eudicots); presence in leaves based on published records (West 1969; Metcalfe and Chalk 1950, 1979, 1983; Metcalfe 1987; Napp-Zinn 1973; Gregory and Baas 1989; Bakker 1992; Bakker and Gerritsen 1992b; Bakker and Baas 1993). Ordinal classification based on APG (2003)

\begin{tabular}{|c|c|c|c|}
\hline Order & Family & Flowers & Leaves \\
\hline \multirow[t]{3}{*}{ Austrobaileyales } & Illiciaceae & + & + \\
\hline & Schisandraceae & + & + \\
\hline & Trimeniaceae & + & + \\
\hline Nymphaeales & Cabombaceae & - & + \\
\hline \multirow[t]{3}{*}{ Magnoliales } & Annonaceae & - & + \\
\hline & Magnoliaceae & - & + \\
\hline & Myristicaceae & + & + \\
\hline \multirow[t]{4}{*}{ Laurales } & Calycanthaceae & + & - \\
\hline & Hernandiaceae & + & + \\
\hline & Lauraceae & + & + \\
\hline & Monimiaceae & + & + \\
\hline Piperales & Saururaceae & $?$ & + \\
\hline \multirow[t]{2}{*}{ Basal Eudicots } & Buxaceae & + & - \\
\hline & Trochodendraceae & $?$ & + \\
\hline Ranunculales & Menispermaceae & - & + \\
\hline Berberidopsidales & Berberidopsidaceae & - & - \\
\hline Gunnerales & Gunneraceae & $?$ & + \\
\hline core eudicots & Dilleniaceae & $?$ & + \\
\hline \multirow[t]{10}{*}{ Caryophyllales } & Aizoaceae & $?$ & + \\
\hline & Amaranthaceae & $?$ & + \\
\hline & Basellaceae & + & + \\
\hline & Cactaceae & + & + \\
\hline & Didiereaceae & + & + \\
\hline & Hectorellaceae & $?$ & + \\
\hline & Phytolaccaceae & - & + \\
\hline & Plumbaginaceae & - & + \\
\hline & Polygonaceae & - & + \\
\hline & Portulaceae & $?$ & + \\
\hline \multirow{2}{*}{ Santalales } & Loranthaceae & $?$ & + \\
\hline & Opiliaceae & $?$ & + \\
\hline \multirow[t]{2}{*}{ Saxifragales } & Crassulaceae & - & + \\
\hline & Hamamelidaceae & $?$ & + \\
\hline Vitales & Vitaceae & $?$ & + \\
\hline \multirow[t]{5}{*}{ Crossosomatales } & Aphloiaceae & - & + \\
\hline & Geissolomataceae & - & + \\
\hline & Ixerbaceae & + & - \\
\hline & Staphyleaceae & - & + \\
\hline & Strasburgeriaceae & + & + \\
\hline \multirow[t]{2}{*}{ Myrtales } & Combretaceae & $?$ & + \\
\hline & Crypteroniaceae & $?$ & + \\
\hline
\end{tabular}


Table 2. (Continued)

\begin{tabular}{|c|c|c|c|}
\hline Order & Family & Flowers & Leaves \\
\hline & Lythraceae & - & + \\
\hline & Melastomataceae & ? & + \\
\hline & Myrtaceae & - & + \\
\hline & Onagraceae & + & + \\
\hline & Vochysiaceae & $?$ & + \\
\hline Geraniales & Geraniaceae & ? & + \\
\hline Zygophyllales & Zygophyllaceae & $?$ & + \\
\hline Celastrales & Celastraceae & - & + \\
\hline \multirow[t]{4}{*}{ Oxalidales } & Connaraceae & - & + \\
\hline & Cunoniaceae & + & + \\
\hline & Elaeocarpaceae & - & + \\
\hline & Tremandraceae & - & + \\
\hline \multirow[t]{21}{*}{ Malpighiales } & Achariaceae & $?$ & + \\
\hline & Bonnetiaceae & $?$ & + \\
\hline & Caryocaraceae & $?$ & + \\
\hline & Chrysobalanaceae & - & + \\
\hline & Dichapetalaceae & - & + \\
\hline & Elatinaceae & $?$ & + \\
\hline & Erythroxylaceae & - & + \\
\hline & Euphorbiaceae & - & + \\
\hline & Goupiaceae & $?$ & + \\
\hline & Humiriaceae & $?$ & + \\
\hline & Linaceae & - & + \\
\hline & Malpighiaceae & - & + \\
\hline & Medusagynaceae & $?$ & + \\
\hline & Ochnaceae & - & + \\
\hline & Passifloraceae & $?$ & + \\
\hline & Picrodendraceae & - & + \\
\hline & Rhizophoraceae & + & + \\
\hline & Salicaceae & - & + \\
\hline & Trigoniaceae & $?$ & + \\
\hline & Turneraceae & - & + \\
\hline & Violaceae & - & + \\
\hline \multirow[t]{3}{*}{ Fabales } & Fabaceae (caesalpinioids) & + & + \\
\hline & Fabaceae (mimosoids) & - & + \\
\hline & Fabaceae (papilionoids) & - & + \\
\hline \multirow[t]{5}{*}{ Rosales } & Moraceae & - & + \\
\hline & Rosaceae & - & + \\
\hline & Rhamnaceae & + & + \\
\hline & Ulmaceae & - & + \\
\hline & Urticaceae & + & + \\
\hline \multirow[t]{2}{*}{ Fagales } & Betulaceae & - & + \\
\hline & Fagaceae & + & + \\
\hline Cucurbitales & Anisophylleaceae & - & + \\
\hline \multirow{2}{*}{ Malvids } & Perrottetia & - & + \\
\hline & Tapisciaceae & $?$ & + \\
\hline \multirow[t]{2}{*}{ Brassicales } & Brassicaceae & - & + \\
\hline & Capparaceae & $?$ & + \\
\hline
\end{tabular}


Table 2. (Continued)

\begin{tabular}{|c|c|c|c|}
\hline Order & Family & Flowers & Leaves \\
\hline & Gyrostemonaceae & $?$ & + \\
\hline & Moringaceae & - & + \\
\hline & Resedaceae & - & + \\
\hline & Tropaeolaceae & - & + \\
\hline \multirow[t]{8}{*}{ Malvales } & Bixaceae & + & + \\
\hline & Cistaceae & - & + \\
\hline & Cochlospermaceae & $?$ & + \\
\hline & Dipterocarpaceae & + & + \\
\hline & Malvaceae & + & + \\
\hline & Neuradaceae & $?$ & + \\
\hline & Sarcolaenaceae & $?$ & + \\
\hline & Thymelaeaceae & - & + \\
\hline \multirow[t]{7}{*}{ Sapindales } & Anacardiaceae & - & + \\
\hline & Burseraceae & + & + \\
\hline & Kirkiaceae & $?$ & + \\
\hline & Meliaceae & - & + \\
\hline & Rutaceae & - & + \\
\hline & Sapindaceae & + & + \\
\hline & Simaroubaceae & - & + \\
\hline \multirow[t]{2}{*}{ Cornales } & Cornaceae & - & + \\
\hline & Nyssaceae & - & + \\
\hline \multirow[t]{8}{*}{ Ericales } & Cyrillaceae & $?$ & + \\
\hline & Ericaceae & - & + \\
\hline & Marcgraviaceae & $?$ & + \\
\hline & Myrsinaceae & $?$ & + \\
\hline & Pentaphylacaceae & $?$ & + \\
\hline & Polemoniaceae & - & + \\
\hline & Sapotaceae & - & + \\
\hline & Theaceae & - & + \\
\hline \multirow[t]{2}{*}{ Lamiids } & Acanthaceae & $?$ & + \\
\hline & Boraginaceae & $?$ & + \\
\hline \multirow[t]{4}{*}{ Gentianales } & Apocynaceae & - & + \\
\hline & Gentianaceae & - & + \\
\hline & Loganiaceae & - & + \\
\hline & Rubiaceae & - & + \\
\hline \multirow[t]{2}{*}{ Lamiales } & Plantaginaceae & - & + \\
\hline & Verbenaceae & - & + \\
\hline Solanales & Solanaceae & - & + \\
\hline Campanulids & Desfontainiaceae & - & + \\
\hline \multirow[t]{3}{*}{ Aquifoliales } & Aquifoliaceae & - & + \\
\hline & Cardiopteridaceae & - & + \\
\hline & Stemonuraceae & - & + \\
\hline
\end{tabular}

Present (+); absent (-); not studied (?)

nales and Urticales contain a high proportion of taxa with (unspecified) mucilage cells but do not comment further. These orders (although not necessarily all of their families), with the exception of Ericales now appear in fabids (APG 2003). In contrast, in traditional 


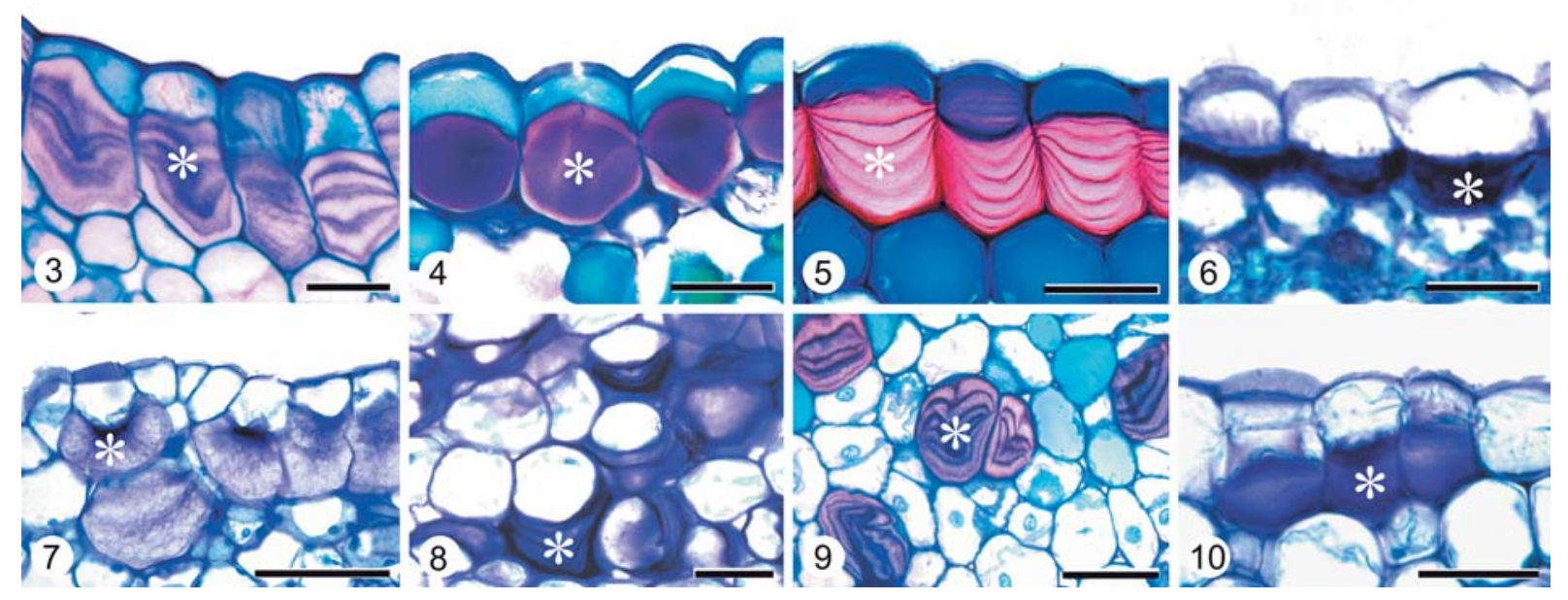

Figs. 3-10. Special mucilage cells in floral organs with thickened mucilaginous inner cell wall (asterisk). 3 Connarus conchocarpus F. Muell. (Connaraceae) (PKE 9074, cult. Australia), sepal, adaxial epidermis. 4 Geissois biagiana F. Muell. (Cunoniaceae) (PKE 9211, Australia), sepal, adaxial epidermis. 5 Tetratheca thymifolia Sm. (Tremandraceae) (PKE 6144, Australia) sepal, abaxial epidermis. 6 Sauvagesia cf. erecta L. (Ochnaceae) (PKE 00-18, Brazil), sepal, abaxial epidermis. 7 Polygonanthus amazonicus (Anisophylleaceae) (s. nom, s. n., received by A. M. Juncosa, Brazil), sepal, adaxial epidermis. 8 Ixerba brexioides A. Cunn. (Ixerbaceae) (M. J. Bayly 1629, New Zealand), sepal, mesophyll. 9 Strasburgeria robusta Guillaumin (Strasburgeriaceae) (B. Suprin, s.n., New Caledonia; Matthews and Endress 2005a), gynoecium, mesophyll. 10 Perrottetia longistylia Rose (Malvids, insertae sedis) (PKE 97-122, Costa Rica), sepal, abaxial epidermis. Scale bars: Figs 3-6, $10=25 \mu \mathrm{m}$, Figs 7, $8=50 \mu \mathrm{m}$, Fig. $9=100 \mu \mathrm{m}$

classifications of Malvales, organs with mucilage cells were believed to be of taxonomic value (synapomorphic?) for the order (Rao and Ramayya 1984, Gregory and Baas 1989), and although consistently present in the leaves of all families in the current (expanded) Malvales, their presence no longer distinguishes them from other orders.

A pattern is also discernable with respect to the location of the special and unspecified mucilage cells within a flower. Special mucilage cells are almost always present in the sepals, which are thick ( $>2$ cell layers thick) and are rare in the gynoecium (only Cunoniaceae, Anisophylleaceae, Strasburgeriaceae). They are primarily present in the epidermis (and hypodermis) and less commonly in the mesophyll, and when in the epidermis, they are almost always on the abaxial side. In contrast, unspecified mucilage cells are not restricted to the sepals, but are rather present in all (or most) floral organs ( $\sim 60 \%$ of taxa) or in the perianth ( $\sim 40 \%$ of taxa), but are never (or only very rarely) present in the androecium alone. They are also primarily found in the mesophyll of organs within the flower. However, there appears to be no correlation between the specific position of mucilage cells in floral organs and its systematic distribution. Unfortunately it was not possible to compare leaves and flowers (with respect to the position of mucilage cells within an organ) as leaf surveys tended to be restricted to description of the epidermis only (e.g. Metcalfe and Chalk 1950).

A limiting factor in the assessment of the distribution of special mucilage cells is their poor preservation in paraplast sections as compared to plastic sections. To gain a better idea of their distribution, a broad survey of flowers using plastic-sectioned material stained with ruthenium red and toluidine blue is needed, including comparison of different developmental stages to assess at what floral 


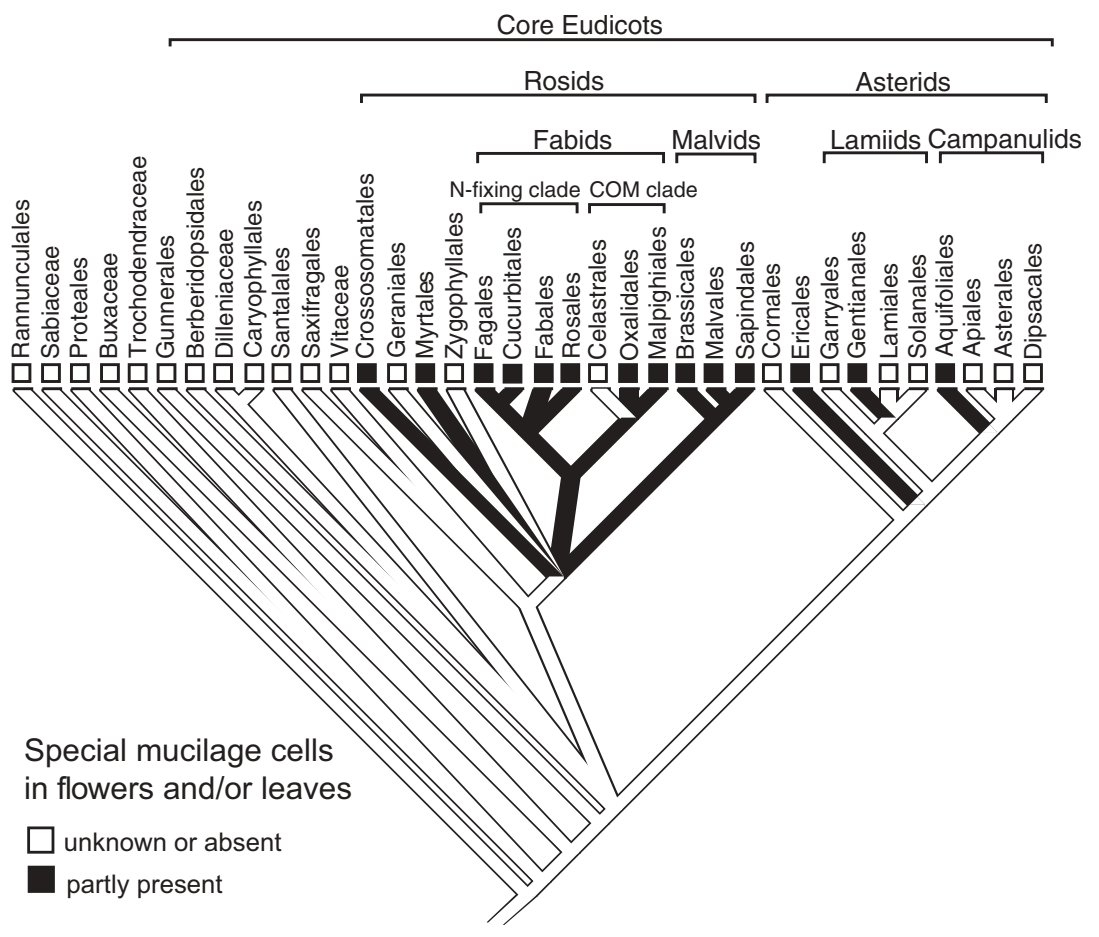

Fig. 11. Presence of special mucilage cells in flowers (our original observations) and/or leaves (published records) in orders of eudicots (topology modified after APG 2003 and Soltis et al. 2005; soft polytomy setting of MacClade 4.07 used for illustration)

stage these cells arise. Significant is that these special mucilage cells are present in organs of both advanced buds and open flowers, as they potentially represent just a 'stage' in mucilage cell development (between the appearance of the mucilage cell and disappearance of the cytoplasm due to an increase in the volume of the mucilaginous cell wall, as seen in unspecified mucilage cells). Rather, in special mucilage cells, it appears that the complete reduction/disappearance of the cytoplasm has been arrested, leaving a visible (and distinct) portion of cytoplasm within the cell.

The distribution of special mucilage cells within sepals (abaxial epidermis) or leaves (adaxial epidermis) also shows an interesting correlation, leading to the question of their function. In both cases they are present on the exposed surface of the organ (upper exposed surface of the leaf), perhaps indicating a protective function for the enclosed organs of the flower (in bud) or the leaf tissues below the adaxial epidermis. In seeds, it is the outer cell wall that is thickened and when in contact with water the mucilaginous cells swell and burst coating the seeds with a film of mucilage (Fahn 1974, Corner 1976, Esau 1977). This film of mucilage is believed to serve a number of possible functions such as reducing dispersal by aiding adherence of seeds to soil after release, or alternatively adhering to animals for dispersal, it may cause a specific reduction in the weight of the seed in water, or it may prevent desication during germination or inhibit germination in waterlogged environments by hindering the passage of oxygen (Fahn 1974). It is not known what happens when special mucilage cells (inner cell wall mucilaginous) come into contact with water. Clearly much work is still needed to establish the function(s) of these cells in both leaves and flowers.

\section{General comments and conclusions}

One may ask what have we learnt from these studies? When we first began our comparative studies with Anisophylleaceae (Cucurbitales) 
and Cunoniaceae (Oxalidales) (Matthews et al. 2001, Schönenberger et al. 2001) we compiled a tentative list of 'special shared features' (potential synapomorphies) which were expanded to include additional features in our first ordinal study (Oxalidales, Matthews and Endress 2002). Some of these 'special shared features' turned out to be more widespread than anticipated (from what was known in the literature). Mucilage cells in flowers (discussed above) were among the new features found. Their wider distribution does not, however, make them less valuable, but rather less defining for specific clades. Our studies demonstrate that close investigation of the flower yields interesting, new features, which may either turn out to be more widespread and thus be potential synapomorphies for larger groups (such as special mucilage cells in rosids) or be potential synapomorphies for smaller groups (such as large, 3-traced involute valvate petals enwrapping a group of stamens in the combined families Elaeocarpaceae and Tremandraceae).

The framework in which we have carried out these ordinal studies and the consistency we have tried to maintain between them, forms a basis for similar studies on other large groups. As mentioned in the Introduction, our next focus will be on the floral structure and systematics of selected clades within the very large order Malpighiales. We hope to reveal more characteristics in floral structure and to propose potential synapomorphies for this diverse order. Also, by combining these results with those of Oxalidales and Celastrales, we hope to come closer to a characterization of the entire COM clade (provided this clade ultimately becomes well supported by molecular studies), thus working towards a better understanding of 'rosid flowers' (Endress and Matthews 2006). However, whether the features we expose are indeed synapomorphies for these groups will remain a question until the phylogenetic resolution between the orders of the rosids improves.
M. von Balthazar and A. Kocyan are thanked for their observation of their microtome sections for flowering material of Malvaceae (Bombacaceae) and Dipterocarpaceae, respectively. We thank D. Ama, I. P. Astuti, M. von Balthazar, M. Bayly, A. Bohte, D. Decker-Walters, U. Eggli, R. Elick, M. Endress, A. George, J. Gomez-Laurito, B. Hammel, B. Hyland, G. T. Jane, A. M. Juncosa, A. Kellow, A. Kocyan, D. Lorence, J. Manning, L. McDade, T. McFarlane, T. Müller, R. Omlor, J-C. Pintaud, E. Robbrecht, E. Sandoval, J. Schönenberger, B. Suprin, W. Takeuchi, T. TrinderSmith, and K. Wood, for providing valuable material for the ordinal studies. The second author thanks B. Haber, B. Gray, B. Hyland, R. Schmid, E. Rakotobe, F.B. Sampson, and H. Tére for support in the field. S. Renner, L. Zhang, B. Gravendeel and M. Simmons are gratefully thanked for unpublished information on the phylogenies of Cucurbitales, Oxalidales and Celastrales. R. Sigrist is thanked for the paraplast (and some of the plastic) sections, and U. Jauch for support with the SEM. This publication is part of a project of the second author, financially supported by the Swiss National Foundation (grant no. 3100059149.99/1) and Deep Time (grant no. DEB0090283).

Appendix I. Mucilage cell type and location in floral organs and leaves (published records, see below) of basal angiosperms and eudicots (monocots not considered). With the exception of the asterids surveyed (where only the number of genera and species are listed in brackets), the genera are listed for all families whose floral organs were surveyed. Numbers in brackets following the genus represents the number of species surveyed (when $>1$ studied)

\begin{tabular}{lll}
\hline Taxa & Flower & Leaf \\
\hline AUSTROBAILEYALES & & \\
Illiciaceae & & $+\mathrm{um}$ \\
Illicium (2) & $+\mathrm{u}$ & + iue \\
Schisandraceae & $+\mathrm{u}$ & \\
Kadsura & $+\mathrm{uam}$ & \\
Schisandra (2) &,$-+\mathrm{uam}$ & $+\mathrm{u}$ \\
Trimeniaceae & & \\
Piptocalyx & $+\mathrm{u}$ & \\
Nymphaeales & & $+\mathrm{uem}$ \\
Cabombacaceae & - & \\
\hline
\end{tabular}


Appendix I. (Continued)

\begin{tabular}{|c|c|c|}
\hline Taxa & Flower & Leaf \\
\hline \multicolumn{3}{|l|}{ MAGNOLIIDS } \\
\hline \multicolumn{3}{|l|}{ MAGNOLIALES } \\
\hline Annonaceae & & + ui \\
\hline (Ancana, Annona, & - & \\
\hline Artabotrys, & & \\
\hline Asimina, & & \\
\hline \multicolumn{3}{|l|}{ Cananga, } \\
\hline \multirow{3}{*}{\multicolumn{3}{|c|}{$\begin{array}{l}\text { Monodora (2), } \\
\text { Polyalthia, } \\
\text { Stelechocarpus) }\end{array}$}} \\
\hline & & \\
\hline & & \\
\hline Myristicaceae & & + um \\
\hline \multicolumn{3}{|l|}{$\begin{array}{l}\text { Mauloutchia, } \\
\text { Virola) }\end{array}$} \\
\hline Myristica (3) &,-+ uam & \\
\hline Magnoliaceae & & $+\mathrm{i}$ \\
\hline \multicolumn{3}{|l|}{$\begin{array}{l}\text { Magnolia (2), } \\
\text { Michelia) }\end{array}$} \\
\hline \multicolumn{3}{|l|}{ LAURALES } \\
\hline Calycanthaceae & $+\mathrm{u}$ & - \\
\hline Hernandiaceae & & $+u m$ \\
\hline Hernandia & + uam & \\
\hline Lauraceae & & + um \\
\hline \multicolumn{3}{|l|}{$\begin{array}{l}\text { Persea (2), } \\
\text { Umbellularia) }\end{array}$} \\
\hline Adenodaphne & + uam & \\
\hline Cassytha & + uam & \\
\hline Cinnamomum (2) &,-+ uam & \\
\hline Gamanthera & + uam & \\
\hline Laurus & + uam & \\
\hline Litsea & + uam & \\
\hline Ocotea & + uam & \\
\hline Monimiaceae & $+\mathrm{u}$ & $+\mathrm{u}$ \\
\hline \multicolumn{3}{|l|}{ PIPERALES } \\
\hline Saururaceae & $?$ & $+\mathrm{uh}$ \\
\hline \multicolumn{3}{|l|}{ BASAL EUDICOTS } \\
\hline Buxaceae & & - \\
\hline Pachysandra & $+\mathrm{u}(?)$ & \\
\hline Trochodendraceae & $?$ & + um \\
\hline \multicolumn{3}{|l|}{ PROTEALES } \\
\hline Proteaceae & $?$ & + um \\
\hline \multicolumn{3}{|l|}{ RANUNCULALES } \\
\hline Menispermaceae & - & + uem \\
\hline CORE EUDICOTS & & \\
\hline Dilleniaceae & $?$ & + um \\
\hline
\end{tabular}

Appendix I. (Continued)

\begin{tabular}{|c|c|c|}
\hline Taxa & Flower & Leaf \\
\hline \multicolumn{3}{|l|}{ GUNNERALES } \\
\hline Gunneraceae & $?$ & $+\mathrm{um}$ \\
\hline BERBERIDOPSIDALES & & \\
\hline Berberidopsidaceae & $?$ & - \\
\hline Berberidopsis & - & \\
\hline \multicolumn{3}{|l|}{ SANTALALES } \\
\hline Loranthaceae & ? & + ue \\
\hline Opiliaceae & $?$ & + um \\
\hline \multicolumn{3}{|l|}{ CARYOPHYLLALES } \\
\hline Aizoaceae & ? & $+u m$ \\
\hline Amaranthaceae & $?$ & + ue \\
\hline Basellaceae & & $+\mathrm{um}$ \\
\hline Boussingaultia & + uam & \\
\hline Cactaceae & & + ue \\
\hline Pereskia & + uam & \\
\hline Didiereaceae & $?$ & + um \\
\hline Hectorellaceae & $?$ & $+\mathrm{u}$ \\
\hline Phytolaccaceae & & + iueh \\
\hline Phytolacca & - & \\
\hline Plumbaginaceae & & $+\mathrm{u}$ \\
\hline Armeria & - & \\
\hline Polygonaceae & & + iueh \\
\hline Polygonum (3) & - & \\
\hline Portulacaceae & $?$ & $+\mathrm{um}$ \\
\hline \multicolumn{3}{|l|}{ SAXIFRAGALES } \\
\hline Crassulaceae & & $+\mathrm{um}$ \\
\hline $\begin{array}{l}\text { (Aeonium }(2), \\
\text { Grenovia, } \\
\text { Kalanchoe, } \\
\text { Sedum) }\end{array}$ & - & \\
\hline Hamamelidaceae & - & + iue \\
\hline Saxifragaceae & $?$ & $+\mathrm{i}$ \\
\hline \multicolumn{3}{|l|}{ VITALES } \\
\hline Vitaceae & $?$ & $+u$ \\
\hline \multicolumn{3}{|l|}{ ROSIDS } \\
\hline \multicolumn{3}{|l|}{ CROSSOSOMATALES } \\
\hline Aphloiaceae & & + ue \\
\hline Aphloia & - & \\
\hline Crossosomataceae & & - \\
\hline Crossosoma & - & \\
\hline Ixerbaceae & & $?$ \\
\hline Ixerba & + suam & \\
\hline Geissolomataceae & & + iue \\
\hline Geissoloma & - & \\
\hline Stachyuraceae & & - \\
\hline Stachyurus & - & \\
\hline Staphyleaceae & & + iue \\
\hline
\end{tabular}


Appendix I. (Continued)

\begin{tabular}{|c|c|c|}
\hline Taxa & Flower & Leaf \\
\hline Staphylea & - & \\
\hline Strasburgeriaceae & & + uehm \\
\hline Strasburgeria & + suam & \\
\hline MYRTALES & & \\
\hline Combretaceae & $?$ & + ue \\
\hline Crypteroniaceae & $?$ & + ue \\
\hline Lythraceae & & + iuem \\
\hline (Cuphea (2), Rotala) & - & \\
\hline Melastomataceae & $?$ & + iue \\
\hline Myrtaceae & & + ue \\
\hline $\begin{array}{l}\text { (Chamaelaucium, } \\
\text { Darwinia, Eugenia, } \\
\text { Tristania) }\end{array}$ & - & \\
\hline Onagraceaae & & + iuem \\
\hline Fuchsia & + uam & \\
\hline Lopezia & + uam & \\
\hline Oenothera & + uam & \\
\hline Vochysiaceae & $?$ & + siue \\
\hline GERANIALES & & \\
\hline $\begin{array}{l}\text { Geraniaceae } \\
\text { ZYGOPHYLLALES }\end{array}$ & $?$ & + ue \\
\hline Zygophyllaceae & $?$ & + ue \\
\hline FABIDS & & \\
\hline CELASTRALES & & \\
\hline Celastraceae & & + ium \\
\hline $\begin{array}{l}\text { (Brexia, Denhamia, } \\
\text { Euonymus, } \\
\text { Hippocratea, } \\
\text { Maytenus, } \\
\text { Pleurostylia, } \\
\text { Salacighia, } \\
\text { Siphonodon } \\
\text { (2), Stackhousia) }\end{array}$ & - & \\
\hline Lepidobotryaceae & & - \\
\hline Lepidobotrys & - & \\
\hline Parnassiaceae & & $?$ \\
\hline Parnassia (2) & - & \\
\hline OXALIDALES & & \\
\hline Brunelliaceae & & - \\
\hline Brunellia & - & \\
\hline Cephalotaceae & & - \\
\hline Cephalotus & - & \\
\hline Connaraceae & & + siue \\
\hline Cnestis & + sphe & \\
\hline Connarus & + spe & \\
\hline Cunoniaceae & & + sue \\
\hline
\end{tabular}

Appendix I. (Continued)

\begin{tabular}{|c|c|c|}
\hline Taxa & Flower & Leaf \\
\hline $\begin{array}{l}\text { (Acsmithia, } \\
\text { Ceratopetalum, } \\
\text { Schizomeria }\end{array}$ & - & \\
\hline Geissois (2) & + sph,+ suaehm & \\
\hline Gillbeea) & + spe & \\
\hline Elaeocarpaceae & & + ue \\
\hline $\begin{array}{l}\text { (Aristotelia, } \\
\text { Elaeocarpus, } \\
\text { Crinodendron, } \\
\text { Sloanea, } \\
\text { Vallea) }\end{array}$ & - & \\
\hline $\begin{array}{l}\text { Oxalidaceae } \\
\text { (Biophytum, Oxalis) }\end{array}$ & - & - \\
\hline Tremandraceae & & + ine \\
\hline Platytheca & + spe & \\
\hline Tetratheca & + spe & \\
\hline $\begin{array}{l}\text { MALPIGHIALES } \\
\text { Achariaceae }\end{array}$ & & + ue \\
\hline $\begin{array}{l}\text { (Caloncoba, } \\
\text { Dovyalis, } \\
\text { Ryparosa) }\end{array}$ & - & \\
\hline Bonnetiaceae & ? & + ueh \\
\hline Caryocaraceae & ? & + ue \\
\hline Chrysobalanaceae & & + ue \\
\hline Chrysobalanus & - & \\
\hline Dichapetalaceae & & +iueh \\
\hline Dichapetalum (2) & - & \\
\hline Elatinaceae & $?$ & + iue \\
\hline Euphorbiaceae & & + siue \\
\hline $\begin{array}{l}\text { (Alchornea, Codiaeum, } \\
\text { Dalechampia, Euphorbia, } \\
\text { Homalanthus (3), Hura, } \\
\text { Macaranga, Mallotus, } \\
\text { Mercurialis, } \\
\text { Pedilanthus } \\
\text { (2), Sapium, } \\
\text { Securinega) }\end{array}$ & - & \\
\hline Erythroxylaceae & & + ue \\
\hline Erythroxylum (2) & - & \\
\hline Goupiaceae & ? & + ue \\
\hline Humiriaceae & ? & + ueh \\
\hline Linaceae & & +iue \\
\hline Linum & - & \\
\hline Malpighiaceae & & + iue \\
\hline $\begin{array}{r}\text { (Gaudichaudia, } \\
\text { Heteropterys) }\end{array}$ & - & \\
\hline
\end{tabular}


Appendix I. (Continued)

\begin{tabular}{|c|c|c|}
\hline Taxa & Flower & Leaf \\
\hline Medusagynaceae & $?$ & + uem \\
\hline Ochnaceae & & + siue \\
\hline $\begin{array}{l}\text { (Campylospermum, } \\
\text { Luxemburgia, } \\
\text { Ochna) }\end{array}$ & - & \\
\hline Sauvagesia & + spe & \\
\hline Passifloraceae & & + cue \\
\hline Passiflora & - & \\
\hline Phyllanthaceae & & \\
\hline Glochidion (2) & - & \\
\hline Picrodendraceae & & $+\mathrm{u}$ \\
\hline $\begin{array}{l}\text { (Choriceras, } \\
\text { Dissiliaria (2), } \\
\text { Micrantheum, } \\
\text { Neoroepera, } \\
\text { Petalostigma, } \\
\text { Sankowskya, } \\
\text { Whyanbeelia) }\end{array}$ & - & \\
\hline Austrobuxus (2) &,$-+\mathrm{sa}$ & \\
\hline Rhizophoraceae & & + iueh \\
\hline $\begin{array}{l}\text { (Ceriops (2), } \\
\text { Rhizophora) }\end{array}$ & - & \\
\hline Gynotroches & + suahm & \\
\hline Salicaceae & & + siueh \\
\hline $\begin{array}{l}\text { (Casearia, } \\
\text { Flacourtia(2), } \\
\text { Oncoba, } \\
\text { Salix, Scolopia) }\end{array}$ & - & \\
\hline Trigoniaceae & $?$ & + sue \\
\hline Turneraceae & & + iue \\
\hline Turnera & - & \\
\hline Violaceae & & + siue \\
\hline $\begin{array}{l}\text { (Hymenanthera, } \\
\text { Melicytus) }\end{array}$ & - & \\
\hline Hybanthus & + spe & \\
\hline Viola $(4)$ &,-+ spe & \\
\hline FABALES & & \\
\hline $\begin{array}{l}\text { Fabaceae } \\
\text { (caesalpinioids) }\end{array}$ & & + ueh \\
\hline $\begin{array}{l}\text { (Bauhinia (2), Caesalpinia (3), } \\
\text { Cassia (3), Cercis, } \\
\text { Delonix, Haematoxylum, } \\
\text { Parkinsonia, Peltophorum) }\end{array}$ & - & \\
\hline Amherstia & + supm & \\
\hline $\begin{array}{l}\text { Fabaceae } \\
\text { (mimosoids) }\end{array}$ & & + siueh \\
\hline
\end{tabular}

Appendix I. (Continued)

\begin{tabular}{|c|c|c|}
\hline Taxa & Flower & Leaf \\
\hline $\begin{array}{l}\text { (Adenanthera, } \\
\text { Archidendron, } \\
\text { Calliandra) }\end{array}$ & - & \\
\hline $\begin{array}{l}\text { Fabaceae } \\
\text { (papilionoids) }\end{array}$ & & + siue \\
\hline (Arachis, & - & \\
\hline \\
\hline \multicolumn{3}{|l|}{ Erythrina, Lathyrus, } \\
\hline \multicolumn{3}{|l|}{ Мисипа, } \\
\hline \multicolumn{3}{|l|}{ Tetragonolobus, } \\
\hline \multicolumn{3}{|l|}{ Trifolium (2), Vicia) } \\
\hline \multicolumn{3}{|l|}{ ROSALES } \\
\hline Moraceae & & + siue \\
\hline $\begin{array}{l}\text { (Broussonetia, } \\
\text { Dorstenia, Morus) }\end{array}$ & - & \\
\hline Rosaceae & & + siue \\
\hline \multicolumn{3}{|l|}{$\begin{array}{l}\text { (Alchemilla, Aruncus, } \\
\text { Filipendula, Malus, } \\
\text { Potentilla, } \\
\text { Spiraea (2)) }\end{array}$} \\
\hline \multicolumn{3}{|l|}{ Rhamnaceae } \\
\hline Ceanothus & + uam & \\
\hline Paliurus & + uam & \\
\hline \multicolumn{2}{|l|}{ Ulmaceae } & + uiem \\
\hline Ulmus & + sam & \\
\hline \multicolumn{2}{|l|}{ Urticaceae } & + uehm \\
\hline Helxine & + upe & \\
\hline & - & \\
\hline \multicolumn{3}{|l|}{$\begin{array}{l}\text { Parietaria } \\
\text { FAGALES }\end{array}$} \\
\hline \multicolumn{2}{|l|}{ Betulaceae } & + cuiehm \\
\hline Carpinus & - & \\
\hline \multicolumn{2}{|l|}{ Fagaceae } & + iue \\
\hline Castanea & + suae & \\
\hline & - & \\
\hline \multicolumn{3}{|l|}{$\begin{array}{l}\text { Llthocarpus } \\
\text { CUCURBITALES }\end{array}$} \\
\hline \multicolumn{2}{|l|}{ Anisophylleaceae } & + ue \\
\hline Anisophyllea & + sae & \\
\hline Combretocarpus & - & \\
\hline Polygonanthus & + speh & \\
\hline Begoniaceae & & - \\
\hline (Begonia, Hillebrandia) & - & \\
\hline Coriariaceae & & - \\
\hline Coriaria & - & \\
\hline Corynocarpaceae & & - \\
\hline Corynocarpus & - & \\
\hline
\end{tabular}


Appendix I. (Continued)

\begin{tabular}{|c|c|c|}
\hline Taxa & Flower & Leaf \\
\hline $\begin{array}{l}\text { Cucurbitaceae } \\
\text { (Alsomitra, Dendrosicyos, } \\
\text { Gynostemma, } \\
\text { Neoalsomitra, } \\
\text { Xerosicyos, Zygosicyos) }\end{array}$ & - & - \\
\hline Datiscaceae & & - \\
\hline Datisca & - & \\
\hline Tetramelaceae & & $?$ \\
\hline Octomeles & - & \\
\hline MALVIDS & & \\
\hline Perrottetia & + sae & + ue \\
\hline $\begin{array}{l}\text { Tapisciaceae } \\
\text { BRASSICALES }\end{array}$ & $?$ & + ue \\
\hline $\begin{array}{l}\text { Brassicaceae } \\
\text { (Aubrietia (2), } \\
\text { Biscutella, } \\
\text { Brassica, Lepidium, } \\
\text { Lunaria, Raphanus, } \\
\text { Vella) }\end{array}$ & - & + siue \\
\hline Capparaceae & $?$ & + ue \\
\hline Gyrostemonaceae & $?$ & + ue \\
\hline Moringaceae & & + iue \\
\hline Moringa & - & \\
\hline Resedaceae & & + siue \\
\hline Reseda & - & \\
\hline Tropaeolaceae & & + ue \\
\hline Tropaeolum & - & \\
\hline MALVALES & & \\
\hline Bixaceae & & + ciue \\
\hline Bixa & + uam & \\
\hline Cistaceae & & + iue \\
\hline $\begin{array}{l}\text { (Cistus, } \\
\text { Helianthemum) }\end{array}$ & - & \\
\hline Fumana & + spe & \\
\hline Cochlospermaceae & $?$ & + ue \\
\hline Dipterocarpaceae & & + ium \\
\hline Monotes (2) & + uam & \\
\hline Malvaceae & & + sciuem \\
\hline Adansonia & + uam & \\
\hline Bombax & + uam & \\
\hline Eriotheca & + uam & \\
\hline Kitaibelia & + uam & \\
\hline Napaea & + uam & \\
\hline Ochroma & + uam & \\
\hline Pachira & + uam & \\
\hline Pavonia (2) & + uam & \\
\hline Plagianthus & + uam & \\
\hline Pseudobombax & + uam & \\
\hline
\end{tabular}

Appendix I. (Continued)

\begin{tabular}{|c|c|c|}
\hline Taxa & Flower & Leaf \\
\hline Sparmannia & + uam & \\
\hline Tilia & + uam & \\
\hline Neuradaceae & $?$ & $+\mathrm{u}$ \\
\hline Sarcolaenaceae & $?$ & + ium \\
\hline Thymelaeaceae & & + siuehm \\
\hline Daphne & - & \\
\hline \multicolumn{3}{|l|}{ SAPINDALES } \\
\hline Anacardiaceae & & + ue \\
\hline $\begin{array}{l}\text { (Amphipterygium, } \\
\text { Anacardium, } \\
\text { Buchanania, } \\
\text { Mangifera) }\end{array}$ & - & \\
\hline Burseraceae & & + uie \\
\hline Bursera & + uam & \\
\hline Kirkiaceae & $?$ & + ue \\
\hline Meliaceae & & + uie \\
\hline Melia & - & \\
\hline Rutaceae & & + siue \\
\hline $\begin{array}{l}\text { (Boenninghausenia, } \\
\text { Ruta, Zanthoxylum, } \\
\text { Zieria) }\end{array}$ & - & \\
\hline Sapindaceae & & + siue \\
\hline $\begin{array}{l}\text { (Acer }(2), \text { Alectryon, } \\
\text { Rhysotoechia })\end{array}$ & - & \\
\hline Koelreuteria & + upe & \\
\hline Simaroubaceae & & + ciue \\
\hline Ailanthus & - & \\
\hline \multicolumn{3}{|l|}{ ASTERIDS } \\
\hline \multicolumn{3}{|l|}{ CORNALES } \\
\hline Cornaceae $(3 / 3)$ & - & + iue \\
\hline Nyssaceae $(1 / 1)$ & - & + ue \\
\hline \multicolumn{3}{|l|}{ ERICALES } \\
\hline Cyrillaceae & $?$ & + siue \\
\hline Ericaceae $(4 / 4)$ & - & + siue \\
\hline Fouquieriaceae (1/1) & - & + sue \\
\hline Marcgraviaceae & $?$ & + ue \\
\hline Myrsinaceae & $?$ & + iue \\
\hline Pentaphylacaceae & $?$ & + iue \\
\hline Polemoniaceae (1/1) & - & + ue \\
\hline Sapotaceae $(1 / 1)$ & - & + iue \\
\hline Theaceae $(1 / 2)$ & - & + sue \\
\hline \multicolumn{3}{|l|}{ LAMIIDS } \\
\hline Acanthaceae & $?$ & + ue \\
\hline Boraginaceae & $?$ & + ue \\
\hline \multicolumn{3}{|l|}{ GENTIANALES } \\
\hline Gentianaceae $(3 / 3)$ & - & + siuehm \\
\hline Rubiaceae (10/10) & - & $+\mathrm{um}$ \\
\hline Apocynaceae $(42 / 50)$ & - & $+\mathrm{um}$ \\
\hline
\end{tabular}


Appendix I. (Continued)

\begin{tabular}{lll}
\hline Taxa & Flower & Leaf \\
\hline Loganiaceae $(4 / 7)$ & - & $+\mathrm{uem}$ \\
LAMIALES & & \\
Plantaginaceae $(6 / 7)$ & - & $+\mathrm{ue}$ \\
Verbenaceae & $?$ & $+\mathrm{ue}$ \\
Orobanchaceae & - & $?$ \\
SOLANALES & & \\
Solanaceae $(4 / 5)$ & - & $+\mathrm{uem}$ \\
CAMPANULIDS & & $+\mathrm{um}$ \\
Desfontainiaceae $(1 / 1)$ & - & $+\mathrm{cuem}$ \\
AQUIFOLIALES & & $+\mathrm{ue}$ \\
Aquifoliaceae $(2 / 2)$ & - & $+\mathrm{ue}$ \\
Cardiopteridaceae $(5 / 5)$ & - & \\
Stemonuraceae $(2 / 2)$ &,-+ saeh & $+\mathrm{u}$ \\
ASTERALES & & $+\mathrm{um}$ \\
Goodeniaceae & $?$ & $+\mathrm{ue}$ \\
Stylidiaceae & $?$ & \\
DIPSACALES & $?$ & \\
Caprifoliaceae & & \\
\hline
\end{tabular}

Present $(+) /$ Absent(-)/not studied (?); Type: special mucilage cell (s) (original observations from this study plus Metcalfe and Chalk 1950, Napp-Zinn 1973, Bredenkamp and Van Wyk 1999, Merino Sutter et al. 2006) /unspecified mucilage cell (u) (original observations from this study plus personal communication by M. von Balthazar and A. Kocyan, Literature used: West 1969; Metcalfe and Chalk 1950, 1983, 1988; Metcalfe 1987; Gregory and Baas 1989; Bakker 1992; Bakker and Gerritsen 1992b; Huber 1993; Endress and Igersheim 1997, 1999; Bakker and Baas 1993; Igersheim and Endress 1997)/"mimic of two cell layers" (c) (NappZinn 1973)/inner membrane (i) (Solereder 1899, 1908); Location flower: sepal (p)/most organs (a), epidermis (e)/hypodermis (h)/mesophyll (m). Description of the type and location of mucilage cells in leaves are a combination from the abovementioned published records

\section{References}

Anisimova G. M. (1983) Begoniaceae. In: Yakovlev M. S. (ed.) Comparative embryology of flowering plants Phytolaccaceae-Thymelaeaceae. Nauka, Leningrad, pp. 144-148.

APG (The Angiosperm Phylogeny Group). (2003) An update of the Angiosperm Phylogeny Group classification for the orders and families of flowering plants: APG II. Bot. J. Linn. Soc. 141: 399-436.

Bakker M. E. (1992) Oil and mucilage cells in dicotyledons: ontogeny, ultrastructure, distribution and systematic value. Doctoral thesis, University of Leiden, Netherlands.

Bakker M. E., Baas P. (1993) Cell-walls in oil and mucilage cells. Acta Bot. Neerl. 42: 133-139.

Bakker M. E., Gerritsen A. F. (1992a) The development of mucilage cells in Hibiscus schizopetalus. Acta Bot. Neerl. 41: 31-42.

Bakker M. E., Gerritsen A. F. (1992b) Oil and mucilage cells in Annona (Annonaceae) and their systematic significance. Blumea 36: 411-438.

Bakker M. E., Gerritsen A. F. (1992c) Leaf anatomy of Cinnamomum Schaeffer (Lauraceae) with special reference to oil and mucilage cells. Blumea 37: 1-30.

Bouchet P. (1973) Etude ultrastructurale de la sécrétion du mucilage chez deux espèces de Tiliacées: Tilia vulgaris Hayne et Entelea arborescens R. Br. Bull. Bot. Soc. Fr. 120: 279292.

Bredenkamp C. L., Van Wyk A. E. (1999) Structure of mucilaginous epidermal cell walls in Passerina (Thymelaeaceae). Bot. J. Linn. Soc. 129: 223-238.

Cameron K. M. (2003) On the phylogenetic position of the New Caledonian endemic families Paracryphiaceae, Oncothecaceae, and Strasburgeriaceae: a comparison of molecules and morphology. Bot. Rev. 68: 428-443.

Corner E. J. H. (1976) The seeds of dicotyledons. Cambridge University Press, Cambridge.

Cronquist A. (1981) An integrated system of classification of flowering plants. Columbia University Press, New York.

Dahlgren R., Rao V. S. (1969) A study of the family Geissolomataceae. Bot. Not. 122: 207-227.

Davies T. J., Barraclough T. G., Chase M. W., Soltis P. S., Soltis D. E., Savolainen V. (2004) Darwin's abominable mystery: insights from a supertree of the angiosperms. Proc. Natl. Acad. Sci. 101: 19041909.

Endress P. K., Matthews M. L. (2006a) Elaborate petals and staminodes in eudicots: structure, function, evolution. Org. Div. Ecol. (in press).

Endress P. K., Matthews M. L. (2006b) First steps towards a floral structural characterization of the major rosid subclades. P1. Syst. Evol. 260: 223-251. 
Endress P. K. Igersheim A. (1997) Gynoecium diversity and systematics of the Laurales. Bot. J. Linn. Soc. 125: 93-168.

Endress P. K. Igersheim A. (1999) Gynoecium diversity and systematics of the basal eudicots. Bot. J. Linn. Soc. 130: 305-393.

Esau K. (1977) Anatomy of seed plants, 2nd edn. John Wiley \& Sons, New York.

Fahn A. (1974) Plant anatomy, 2nd edn. Pergamon Press, Oxford.

Fahn A. (1979) Secretory tissues in plants. Academic Press: New York.

Fahn A. (1988) Secretory tissues in vascular plants. New Phytol. 108: 229-257.

Gregory M., Baas P. (1989) A survey of mucilage cells in vegetative organs of the dictotyledons. Israel J. Bot. 38: 125-174.

Huber H. (1993) Neurada, eine Gattung der Malvales. Sendtnera 1: 7-10.

Igersheim A., Endress P. K. (1997). Gynoecium diversity and systematics of the Magnoliales and winteroids. Bot. J. Linn. Soc. 124: 213-271.

Judd W. S., Olmstead R. G. (2004) A survey of tricolpate (eudicot) phylogenetic relationships. Amer. J. Bot. 91: 1627-1644.

Kårehed J. (2001) Multiple origin of the tropical forest tree family Icacinaceae. Amer. J. Bot. 88: 2259-2274.

Lemmens R. H. M. J. (1989) Heterostyly/Pollen morphology. In: Breteler F. J. (ed.) The Connaraceae - a taxonomic study with emphasis on Africa. AUWP 89-6: 56-72/73-75.

Lyshede O. B. (1977) Studies on the mucilage cells in the leaf of Spartocytisus filipes W. B. Planta 133: 255-260.

Mariani P., Rascio N., Baldan B., Paiero P., Urso T. (1988) Epidermal mucilage cells in leaves of Salix species. Flora 181: 137-145.

Matthews M. L., Endress P. K. (2002) Comparative floral structure and systematics in Oxalidales (Oxalidaceae, Connaraceae, Brunelliaceae, Cephalotaceae, Cunoniaceae, Elaeocarpaceae, Tremandraceae). Bot. J. Linn. Soc. 140: 321-381.

Matthews M. L., Endress P. K. (2004) Comparative floral structure and systematics in Cucurbitales (Corynocarpaceae, Coriariaceae, Tetramelaceae, Datiscaceae, Begoniaceae, $\mathrm{Cu}$ curbitaceae, Anisophylleaceae). Bot. J. Linn. Soc. 145: 129-185.

Matthews M. L., Endress P. K. (2005a) Comparative floral structure and systematics in Crosso- somatales (Crossosomataceae, Stachyuraceae, Staphyleaceae, Aphloiaceae, Geissolomataceae, Ixerbaceae, Strasburgeriaceae). Bot. J. Linn. Soc. 147: 1-46.

Matthews M. L., Endress P. K. (2005b) Comparative floral structure and systematics in Celastrales (Celastraceae, Parnassiaceae, Lepidobotryaceae). Bot. J. Linn. Soc. 149: 129-194.

Matthews M. L., Endress P. K., Schönenberger J., Friis E. M. (2001) A comparison of floral structures of Anisophylleaceae and Cunoniaceae and the problem of their systematic relationships. Ann. Bot. 88: 439-455.

Mauseth J. D. (1980) A stereological morphometric study of the ultrastructure of mucilage cells in Opuntia polyacantha (Cactaceae). Bot. Gaz. 141: 374-378.

Merino Sutter D., Forster P. I., Endress P. K. (2006) Female flowers and systematic position of Picrodendraceae (Euphorbiaceae s.l., Malpighiales). Pl. Syst. Evol. (in press).

Metcalfe C. R. (1987) Anatomy of the dicotyledons 3 (2nd edn.). Clarendon Press, Oxford.

Metcalfe C. R., Chalk L. (1950) Anatomy of the dicotyledons I, II. Clarendon Press, Oxford.

Metcalfe C. R., Chalk L. (1979) Anatomy of the dicotyledons 1 (2nd edn.). Clarendon Press, Oxford.

Metcalfe C. R., Chalk L. (1983) Anatomy of the dicotyledons 2 (2nd edn.). Clarendon Press, Oxford.

Mollenhauer H. H. (1967) The fine structure of mucilage secreting cells of Hibiscus esculentus pods. Protoplasma 63: 353-362.

Napp-Zinn K. (1973) Anatomie des Blattes. II. Angiospermen A, 1. Handbuch der Pflanzenanatomie, Spezieller Teil VIII 2A. Borntraeger, Berlin.

Rao S. R. S., Ramayya N. (1984) Structure and taxonomic distribution of epidermal idioblasts in the Malvales. Indian J. Bot. 7: 117-123.

Savolainen V., Fay M. F., Albach D. C., Backlund A., van der Bank M., Cameron K. M., Johnson S. A., Lledó M. D., Pintaud J.-C., Powell M., Sheahan M. C., Soltis D. E., Soltis P. S., Weston P., Whitten W. M., Wurdack K. J., Chase M. W. (2000) Phylogeny of the eudicots: a nearly complete familial analysis based on $r b c \mathrm{~L}$ gene sequences. Kew Bull. 55: 257-309.

Schönenberger J., Friis E. M., Matthews M. L., Endress P. K. (2001) Cunoniaceae in the Creta- 
ceous of Europe: evidence from fossil flowers. Ann. Bot. 88: 423-437.

Schwarzbach A. E., Ricklefs R. E. (2000) Systematic affinities of Rhizophoraceae and Anisophylleaceae, and intergeneric relationships within Rhizophoraceae, based on chloroplast DNA, nuclear ribosomal DNA, and morphology. Amer. J. Bot. 87: 547-564.

Scott F. M., Bystrom B. G. (1970) Mucilaginous idioblasts in okra, Hibiscus esculentus L. In: Robson N. K. B., Cutler D. F., Gregory M. (eds.) New research in plant anatomy. Academic Press, New York.

Simmons M. P., Clevinger C. C., Savolainen V., Archer R. H., Mathews S., Doyle J. J. (2001a) Phylogeny of the Celastraceae inferred from phytochrome B and morphology. Amer. J. Bot. 88: 313-325.

Simmons M. P., Savolainen V., Clevinger C. C., Archer R. H., Davis J. I. (2001b) Phylogeny of the Celastraceae inferred from 26S nrDNA, phytochrome $\mathrm{B}, a t p \mathrm{~B}, r b c \mathrm{~L}$, and morphology. Molec. Phylogenet. Evol. 19: 353-366.

Singh D. (1955) Embryological studies in Cucumis melo var. pubescens Willd. J. Ind. Bot. Soc. 34: $72-78$.

Solereder H. (1899/1908) Systematische Anatomie der Dicotyledonen I/II. Enke, Stuttgart.

Soltis D. E., Soltis P. S., Chase M. W., Mort M. E., Albach D. C., Zanis M., Savolainen V., Hahn W. H., Hoot S. B., Fay M. F., Axtell M., Swensen S. M., Nixon K. C., Farris J. S. (2000) Angiosperm phylogeny inferred from a combined data set of $18 \mathrm{~S}$ rDNA, $r b c \mathrm{~L}$ and $a t p \mathrm{~B}$ sequences. Bot. J. Linn. Soc. 133: 381-461.

Soltis D. E., Soltis P. S., Endress P. K., Chase M. W. (2005) Phylogeny and evolution of angiosperms. Sinauer, Sunderland, MA.

Sosa V., Chase M. W. (2003) Phylogenetics of Crossosomataceae based on $r b c \mathrm{~L}$ sequence data. Syst. Bot. 28: 96-105.

Stevens P. F. (2001 onwards) Angiosperm Phylogeny Website. http://www.mobot.org/MOBOT/ research/APweb/.
Tobe H., Raven P. H. (1987) Systematic embryology of the Anisophylleaceae. Ann. Missouri Bot. Gard. 74: 1-26.

Trachtenberg S., Fahn A. (1981). The mucilage cells of Opuntia ficus-indica (L.) Mill. - development, ultrastructure, and mucilage secretion. Bot. Gaz. 142: 206-213.

Trognitz B. R., Hermann M. (2001) Inheritance of tristyly in Oxalis tuberosa (Oxalidaceae). Heredity. 86: 564-573.

Tschirch A. (1889) Angewandte Pflanzenanatomie. Vol. 1. Urban und Schwarzenberg, Wien.

Volkens G. (1887) Die Flora der aegyptischarabischen Wüste. Borntraeger, Berlin.

Wagstaff S. J., Dawson M. I. (2000) Classification, origin, and patterns of diversification of Corynocarpus (Corynocarpaceae) inferred from DNA sequences. Syst. Bot. 25: 134-149.

Walliczek H. (1893) Studien über die Membranschleime vegetativer Organe. Jahrb. Wiss. Bot. 25: 209-277.

West W. C. (1969) Ontogeny of oil cells in the woody Ranales. Bull. Torrey Bot. Club 96: 329344.

Zhang L.-B., Renner S. S. (2003) Phylogeny of Cucurbitales inferred from seven chloroplast and mitochondrial loci. Botany 2003 Abstract.

Zhang L.-B., Simmons M. P. (2006) Phylogeny and delimitation of the Celastrales inferred from nuclear and plastid genes. Syst. Bot. 31: 122-137.

Zhang L.-B., Simmons M. P., Kocyan A., Renner S. S. (2006) Phylogeny of the Cucurbitales based on DNA sequences of nine loci from three genomes: implications for morphological and sexual system evolution. Molec. Phylogenet. Evol. 39: 305322.

Address of the authors: M. L. Matthews (e-mail: mmatthews@access.unizh.ch), P. K. Endress (e-mail: pendress@systbot.unizh.ch), Institute of Systematic Botany, University of Zurich, Zollikerstrasse 107, 8008 Zurich, Switzerland. 